\title{
Building Bridges on Immigration
}

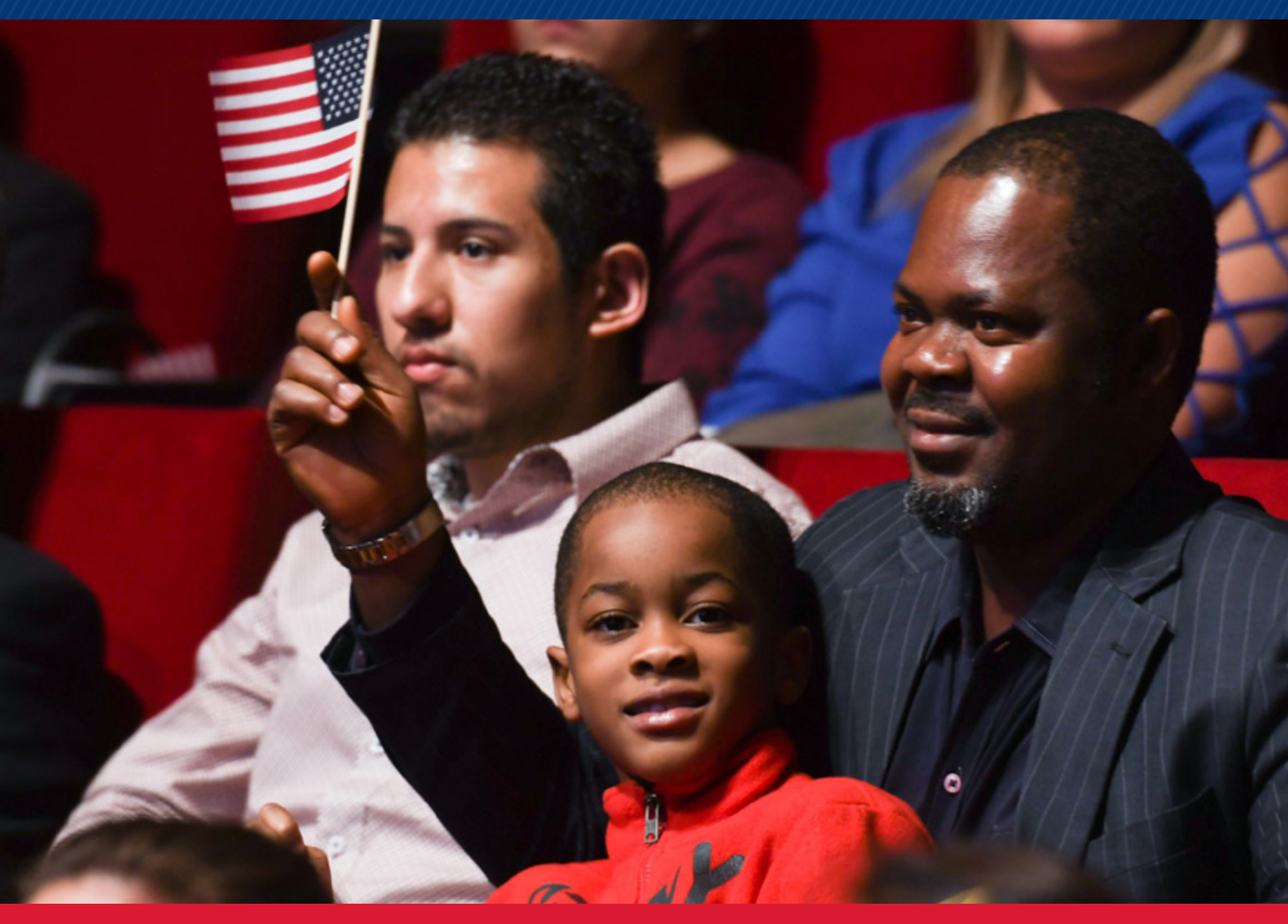

A Report From

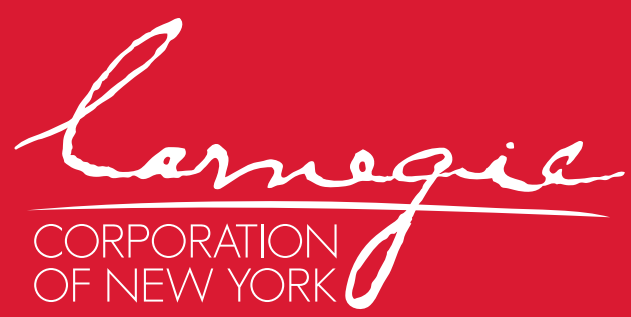

Written by

William H. Woodwell, Jr.

October 2021 
Any lasting and meanitingful. change, regardless of the policy issue, is stronger if it is bipartisan. There will always be outliers, but at the grassiroots level and in Washington, we need agreement among a diverse segment of Americans on immignation reform if it is going to stand the test of time.

- Andrew Geraghty, Program Officer, Strengthening U.S. Democracy, Carnegie Corporation of New York 


\section{CONTENTS}

2 Introduction

3 Carnegie Corporation's Commitment

4 Making a Consensus Case for Change

6 "A Human Rights Story"

$7 \quad$ Alliance Building in Action

8 Bibles, Badges, and Business

9 Advancing the Economic Argument

11 Libertarians, Conservatives Join the Fight

13 Federal Focus Complements Grassroots Power Building

16 Communications and Messaging Matter

16 A Timely - and Necessary - Investment 
A s the COVID-19 crisis wreaked havoc across the United States, opinion polls captured a shift in public understanding and appreciation of U.S. immigrants, whose families and communities were among the hardest hit by the pandemic and its economic shock waves. For example, a September 2020 survey by the Pew Research Center revealed that Americans were viewing immigrants in a more positive light. According to the poll, 60 percent of registered voters said newcomers strengthen American society, compared to less than half (46 percent) in 2016.

For immigrant communities and advocates, these numbers were an encouraging sign during an otherwise difficult moment. However, the extent to which growing support for immigrants in the wake of the COVID19 crisis will translate into more immigrant-friendly policies in Washington and at all levels of government is an open question. The Trump administration's anti-immigrant policies and actions fomented deep divisions and left even deeper scars in immigrant communities across the land. Even at their most optimistic, and with a new administration promising pro-immigrant policies, pro-reform advocates say lasting change is still uncertain.

So how are advocates and their philanthropic allies to respond in this moment? In the eyes of many who have watched the nation's combative immigration debates come and go without much resolution in the way of far-reaching reform, a critical pathway to pro-immigrant policies at all levels may lie in an approach that seems quaint and even nostalgic given the gridlock of recent years: strengthening alliances across interests, sectors, and political points of view. At the same time that philanthropy is investing in building grassroots movements for change, many advocates say that building bridges is also key.

"Our theory of change has been that politics is always a game of addition," said Rebecca Shi. Shi is executive director of the American Business Immigration
Coalition, a Carnegie Corporation of New York grantee that organizes businesses and business associations to promote "commonsense" reforms that are good for immigrants and good for the U.S. economy. "We believe success comes from adding allies and bringing in different voices based on the understanding that Americans and American business are broadly supportive of immigrants."

Ali Noorani has led the National Immigration Forum, a longtime, core Corporation grantee, for more than a decade. Under his leadership, the Forum launched the Bibles, Badges, and Business for Immigration Reform network in 2012 to bring together conservative faith communities, law enforcement, and business leaders in support of immigration reforms. Noorani said that in the wake of the 2020 election and the COVID crisis, the time is right for forging broader consensus on an issue that has for too long divided the country.

"We are seeing real opportunities for engagement with communities that could really make a difference and move the needle politically on this issue," Noorani said.

By supporting the alliance-building work of the National Immigration Forum, the American Business Immigration Coalition, and other similarly minded groups, Noorani said philanthropy has an opportunity to help break the logjam on these issues and advance saner, sounder, and more humane policies that will help immigrants and all Americans.

In this report, we review Carnegie Corporation of New York's support for alliance building on immigration, the history of this work, and opportunities for the future. We also appeal to philanthropy to invest in alliance building as an essential strategy toward shifting U.S. policy, politics, and culture in the direction of advancing and protecting the rights and opportunities of U.S. immigrants. 


\section{CARNEGIE \\ CORPORATION'S \\ COMMITMENT}

C arnegie Corporation of New York is a long-standing philanthropic supporter of organizations and movements that are working to help strengthen the U.S. immigration system in ways that recognize the power and potential of immigrants to strengthen U.S. communities and the economy. The Corporation's grantmaking reflects the life story and beliefs of its founder and namesake, Andrew Carnegie, who immigrated with his family to the United States at age 13 to escape poverty in Scotland. Since 2001, the Corporation has awarded roughly $\$ 200$ million in support for immigrants and immigrant integration at the national, state, and local levels.

"We believe that immigration makes our country, and especially our democracy, stronger, and the Corporation's philanthropy reflects that," said Geri Mannion, director of the Corporation's Strengthening U.S. Democracy program and the Special Opportunities Fund. "We look to invest in solutions that will help create a better future in this country for immigrants, which in turn creates a better economy and more social cohesion for all Americans.”

Since 2001, the Corporation has awarded roughly \$200 million in support for immigrants and immigrant integration at the national, state, and local levels.
For many years, the Corporation has supported multiple strategies on the way to pro-immigrant solutions. One strategy is supporting grassroots organizations at the state and local levels that are pushing a ground-up campaign for change. The Corporation pursues this strategy through both independent grantmaking and its leadership and participation in funder collaboratives such as NEO Philanthropy's Four Freedoms Fund. At the same time, the Corporation has also been a leading supporter of efforts to build alliances on immigration across sectors. While neither strategy has yet delivered the far-reaching, federal pro-immigrant reforms the Corporation and many of its grantee partners are hoping for, Mannion said this is no time to throw in the towel.

"There are real opportunities today for positive progress, but it's only going to happen if we continue to invest at all levels, and if we continue to lift up and recognize our shared interests," Mannion said. She added that building relationships across lines that too often go uncrossed is key. "This is about reaching across the aisle and across the street and across industries and everything else, because that's how people see what they have in common and what they share. And once you do that you start to create a chorus for change that is hard to ignore in Washington or anywhere else." 


\section{MAKING A \\ CONSENSUS CASE \\ FOR CHANGE}

$\mathrm{F}$ or decades, reform of the United States' broken immigration system was a priority that cut across partisan lines and drew support from a range of interests, including business.

Under the Republican administrations of Ronald Reagan and George H. W. Bush in the 1980 s and early 1990s, the federal government created new pathways to permanent residency for undocumented workers, expanded visa programs for temporary workers, and granted temporary protection from deportation to immigrants from countries that were facing armed conflicts, natural disasters, and other crises.

When President George W. Bush took office in 2001, advocates of broader, more lasting policy changes felt they were near the finish line, given the president's vocal support for comprehensive immigration reform. But following the terrorist attacks on September 11 of that year, policymakers and the general public began to view immigration primarily through the lens of national security, creating a much more difficult and heated debate. Congress, with the support of President Bush, attempted to pass comprehensive immigration reform in 2007 but the bill fell short in the Senate. President Bush would

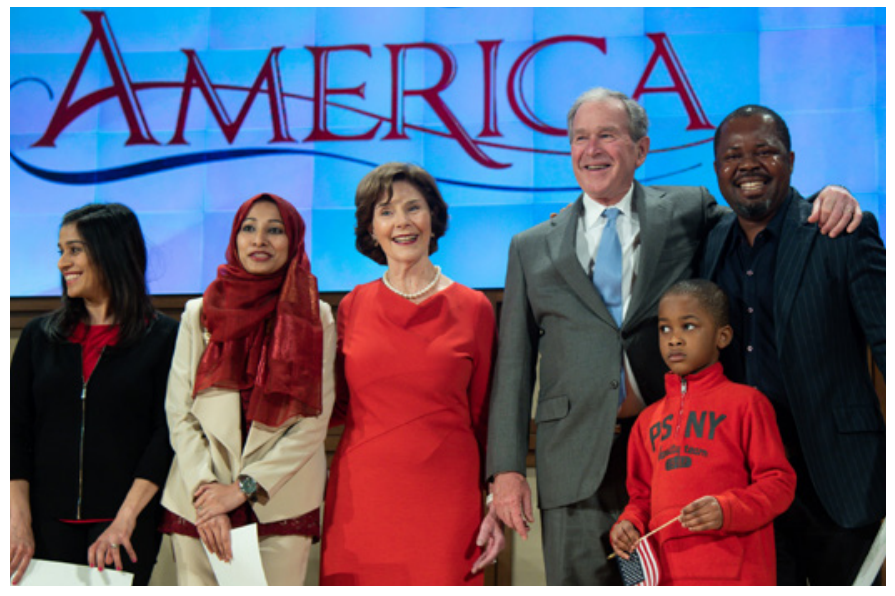

Immigrants participate in an official naturalization ceremony at the George W. Bush Institute in March 2019. Former President Bush and former First Lady Laura Bush delivered remarks noting the significant contributions of immigrants to America. later say that the failure to enact strong and comprehensive immigration reform on his watch was one of his biggest regrets.

Despite the political challenges of advancing broad reforms, Republicans played a key role in driving congressional action on the issue in the post-9/11 years. In 2013, a bipartisan group of lawmakers who became known as the "Gang of Eight" drafted a Senate bill creating a path to citizenship for undocumented immigrants living in the United States.

Throughout this period, leaders from business and other sectors were strong supporters of commonsense immigration reforms. In fact, the U.S. Chamber of Commerce and the National Association of Manufacturers were among the fiercest proponents. Also among the chorus were a range of other interests, including police and faith leaders who were seeing how the country's failed policies were playing out at the local level and contributing to fear, distrust, and hardship among immigrant and refugee communities.

Although it had broad-based support, the 2013 Senate bill died in the House of Representatives. Unable to rely on Congress, President Barack Obama advanced some pro-immigrant actions such as the Deferred Action for Childhood Arrivals (DACA) program, which provides deportation relief and work permits for young undocumented immigrants, known as Dreamers. The president took these actions even as his administration stepped up the federal government's deportation activities with a focus on criminals and recent border crossers. The 2016 election of President Donald J. Trump and his administration's subsequent adoption of a range of harsh anti-immigrant policies closed the door on any hope of bipartisan commonsense reforms. 
Growing polarization has stymied legislative efforts to address the immigration standoff. The most notable immigration policy changes in recent years have been waged through executive orders by the Obama and Trump administrations. But there are limits to this approach.

"Any lasting and meaningful change, regardless of the policy issue, is stronger if it is bipartisan," said Andrew Geraghty, program officer for the Corporation's Strengthening U.S. Democracy program. Geraghty, who oversees the Corporation's alliance-building portfolio, continued, "There will always be outliers, but at the grassroots level and in Washington, we need agreement among a diverse segment of Americans on immigration reform if it is going to stand the test of time."

President Joseph R. Biden signaled a marked shift in tone and approach when he proposed a bill on his first day in office to create a pathway to citizenship for the more than 11 million immigrants living in the United States without proper documentation, many for decades. While the measure faces an uphill climb in a deeply divided Congress, advocates are encouraged that serious reforms are back on the table - and they say the time is right for new investments in bridge building, if only because of the growing urgency of the immigration issue.

\section{For decades, reform of the United States' broken immigration system was a priority that cut across partisan lines and drew support from a range of interests, including business.}

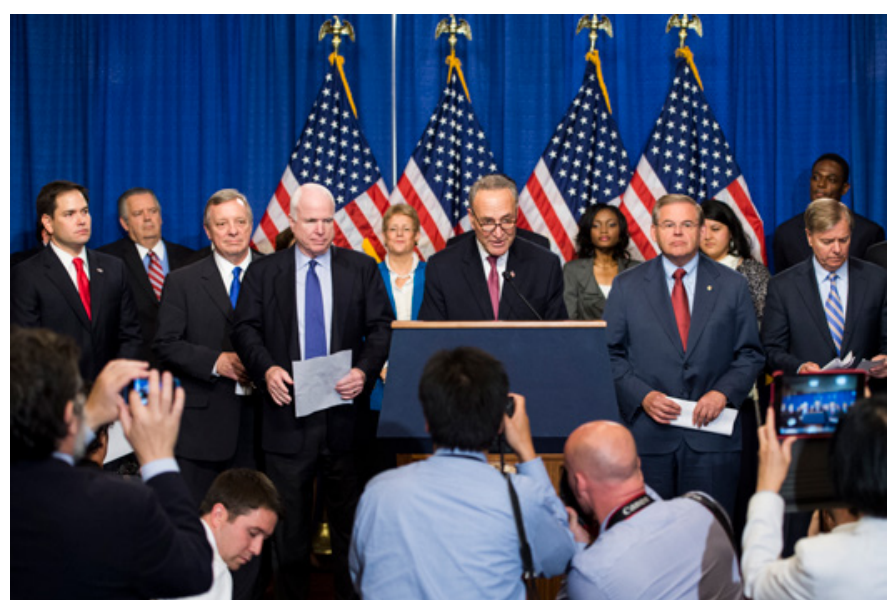

From left, "Gang of Eight" Senators in April 2013: Marco Rubio, R-Fla., Richard Durbin, D-Ill., John McCain, R-Ariz., Chuck Schumer, D-N.Y., Bob Menendez, D-N.J., and Lindsey Graham, R-S.C., hold their news conference with advocates of immigration reform to outline a "bipartisan immigration reform proposal." CREDIT: BILL CLARK/CQ ROLL CALL 


\section{"A HUMAN \\ RIGHTS STORY"}

$\mathrm{H}$ ow urgent are the problems? Undocumented immigrants and their families, who often include American citizens, face severe challenges when it comes to everything from finding a good job to a decent education to quality health care. Many live in fear of any contact with police or government. Meanwhile, the Central American corridor and the U.S.-Mexico border have become chaotic and dangerous places for immigrant and migrant families and people seeking asylum. Children have been separated from their families, and individuals and families have been sent home to countries they were trying to flee because of the threat of sexual assault, violence, and death. To add to the problems, given the last administration's policies, U.S. systems for awarding visas for work and travel, granting asylum, and naturalizing legal permanent residents all are in various states of disarray.

Given how support for immigrants grew in the wake of reports of families being separated at the border in 2018 and 2019, it appears that a broad swath of the American public understands the failures and the inhumanity of the current system. To the extent that advocates can advance commonsense reforms that are seen as solving urgent problems, benefiting immigrants, and advancing economic growth, there's a feeling that the next few years hold real potential for historic change.
Jeremy Robbins is executive director of New American Economy, a Corporation grantee dedicated to "fighting for smart federal, state, and local immigration policies that help grow our economy and create jobs for all Americans." He is also the grandson of Jewish immigrants who fled Russia because of anti-Semitic violence and pogroms in the early 1900 s.

"I think deep in my blood that immigration is a human rights story," Robbins said. "But to change the system, you can't just make the human rights case. You also have to make the case that change is in the interest of all communities - and that means helping people see and appreciate the immigrants all around them and helping them see how those immigrants make this a better, stronger, and more prosperous country."

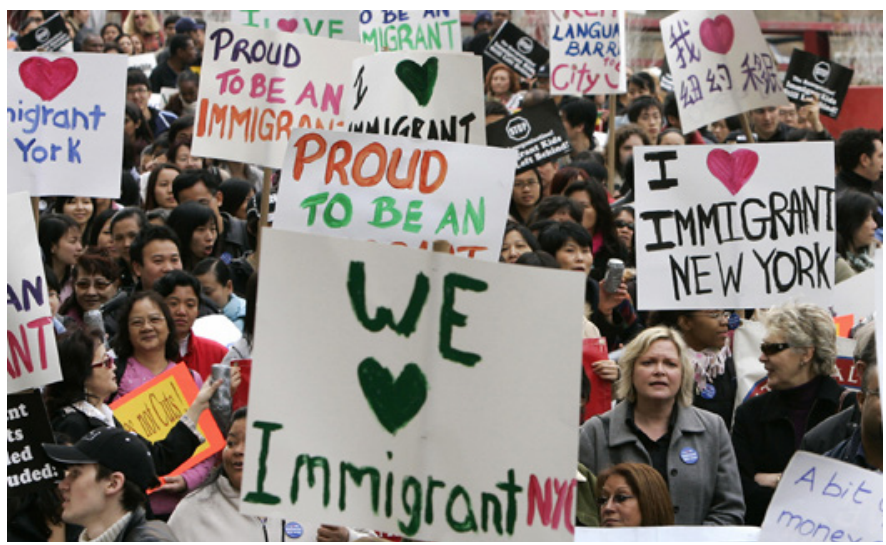

In March 2007, immigrants and advocates march to New York's City Hall for immigration reform. U.S. President George W. Bush had expressed hope that a divided U.S. Congress would reach agreement on immigration reform by August. CREDIT: TIMOTHY A. CLARY/AFP VIA GETTY IMAGES 


\section{ALLIANCE BUILDING IN ACTION}

$\mathrm{N}$ ew American Economy was established in 2012 by then-New York City Mayor Michael Bloomberg in an effort to showcase the economic benefits of immigration at the local and state levels across the country. In the organization's first research report, it found that more than 40 percent of Fortune 500 companies were founded by immigrants or their children. It was a key datapoint that created the foundation for New American Economy's subsequent work to spark "better conversations" about the role of immigrants in the U.S. economy and society.

Carnegie Corporation of New York was one of the first funders to join Bloomberg in supporting New American Economy to expand its strategies and programs. Today, it is one of the leading research and advocacy organizations dedicated to building the economic case for immigration reforms at all levels of government. Among its signature partners is the Gateways for Growth Challenge launched by another Corporation grantee, Welcoming America. The challenge is supporting more than 70 communities across the country to pursue programs and policies that welcome and integrate immigrants. New American Economy and Welcoming America support these communities in their efforts by providing customized research on local immigrant contributions, along with tailored technical assistance and grants to create and fund their immigrant-welcoming plans.

\section{What we are trying to do is deep} cultural work. Immigration may be a political fight, but at its core it is a cultural fight, and that means you have to shift the conversation from the ground up about who immigrants are and what they bring to American communities.

- Jeremy Robbins, Executive Director, New American Economy
Robbins emphasizes that many of the communities selected for the initiative are located in politically conservative areas - and that's intentional. "What we are trying to do is deep cultural work," he said. "Immigration may be a political fight, but at its core it is a cultural fight, and that means you have to shift the conversation from the ground up about who immigrants are and what they bring to American communities."

In addition to its local work via the Gateways for Growth Challenge, New American Economy has full-time organizers in key states such as Colorado, Ohio, and Texas who are working to build support for pro-immigrant policies. Robbins said the combination of local and state work has helped fuel a number of policy wins across the country. These include 30 municipal offices dedicated to immigrant inclusion; 23 local strategic plans for immigrant integration; and policies in 22 states that provide in-state college tuition rates for undocumented students.

Given New American Economy's strategic focus on building support for immigrants in conservative and "swing" areas across the country, Robbins said federal lawmakers can't help but notice the pro-immigrant victories happening in their districts and states. "We are focused on bottom-up solutions, with the idea that what's happening in these communities and states can help create momentum for national reform down the road," he said. 


\section{BIBLES, BADGES, AND BUSINESS}

$\mathrm{N}$ ew American Economy is by no means alone in trying to broaden support for immigrants and pro-immigrant reforms among communities and audiences that are too often pigeonholed as immovable in their opinions on these issues. The National Immigration Forum's Bibles, Badges, and Business network doubled in size in the four years after the 2016 election to include more than 21,00o conservative and moderate faith, law enforcement, and business leaders across the country. With the Forum providing support for messaging, coalition building, and advocacy, network members work to engage their members of Congress and shift local narratives about immigrants and immigration.

Like New American Economy, the National Immigration Forum tends to focus its coalition-building work on conservative areas. As part of the Bibles, Badges, and Business initiative, it has built independent organizing and outreach campaigns focused on specific audiences. One example is Women of Welcome, a grassroots effort that has engaged thousands of white evangelical women in the immigration debate, encouraging them to use their faith to frame the issue. According to the Forum's research, roughly 6 million of the 31 million white evangelical women in the country are open to supporting a pathway to citizenship for undocumented immigrants.

Other active tables and task forces created by the Forum include the Evangelical Immigration Table, with more than 17,000 pastors and leaders from the evangelical community nationwide. In January 2021, members of the Table called on Congress and the incoming Biden administration to advance bipartisan reforms. Among the evangelical leaders signing the statement was Walter Kim, president of the National Association of Evangelicals. He said:
"The Scriptures speak powerfully about the dignity of every person and about God's deep love and care for immigrants and refugees. These are people we know personally, who have contributed to the vitality of our churches, communities, and nation. The new Congress and administration have an opportunity to provide overdue moral leadership in fixing our broken immigration system so that it reflects justice and compassion while maintaining the security of our borders."

The National Immigration Forum also created the Law Enforcement Immigration Task Force, members of which include 120 police chiefs, sheriffs, and public safety directors. In a September $2020 \underline{\text { blog expressing }}$ opposition to the Trump administration's efforts to undermine the DACA program, the task force explained why immigration is a priority issue for law enforcement officials across the country:

\section{"When undocumented residents live in fear that interactions with local law enforcement officials could result in deportation, they are less likely to work with police or prosecutors. That hampers our investigation of individual crimes and creates fertile ground for criminal activity: Undocumented immigrants are frequent targets for robbery and workplace exploitation."}

The cross-sector tables managed by the National Immigration Forum engage their members in educational activities, lawmaker outreach, social media campaigns, and other efforts aimed at building understanding of and support for pro-immigrant reforms. 


\section{ADVANCING \\ THE ECONOMIC \\ ARGUMENT}

According to Noorani, the Forum has emphasized coalition building since it was established in the 1980s, but this work shifted into "high gear" after the 2010 defeat of the DREAM Act in the U.S. Senate. The DREAM Act would have provided permanent legal status to young immigrants who entered the United States before age 16. In the wake of the DREAM Act's demise, the Forum's research showed that pro-immigrant reforms drew the least support in parts of the Southeast, Midwest, and Mountain West with large populations of evangelicals and the highest densities of state and local law enforcement personnel, relative to the overall population.

After the 2016 election, Noorani said the Forum expanded and activated its faith and law enforcement networks to speak up in opposition to some of the harshest anti-immigrant measures advanced by the Trump administration, including family separation policies and outright bans on asylum and immigration.

"We helped play a role in getting specific communities to say that these things were wrong, and that helped modulate some of what was going on," he said. Looking forward, he acknowledged that there is "huge work to do" to combat misinformation and disinformation about immigrants. The ultimate goal of the Forum's alliance-building work, he said, is to broaden support for reform measures among more conservative-leaning audiences and lawmakers, especially in conservative and swing districts.
T o facilitate business engagement on immigration issues, the National Immigration Forum is the convenor of the Corporate Roundtable for the New American Workforce, a group of Fortune 500 companies representing diverse industries who work to advance an aligned reform agenda. This work complements the efforts of the American Business Immigration Coalition (ABIC), among other groups, to rally business support for immigrant communities and pro-immigrant policies. With Carnegie Corporation of New York as one of its initial funders, ABIC moved from an initial focus on presenting the business case for reform to state lawmakers in Illinois to a broader focus on activating business support for reform in seven strategically targeted states.

During congressional deliberations on the COVID19 response in the spring of 2020, ABIC activated its networks to help make sure immigrants were included in federal stimulus measures - in part through the provision of stimulus payments to "mixed-status" families consisting of both undocumented and citizen family members. More broadly, the coalition and its members are advocating for a path to citizenship for undocumented immigrants, along with expanded access to visas for both lower-skilled and higher-skilled immigrant workers.

Rebecca Shi said ABIC's bridge-building work includes partnerships with immigrant rights organizations working at the state and local levels. "Some business entities might hold the immigrant rights movement or labor at arm's length, but we think at the end of the day you accomplish big and controversial things with lots of pressure from the outside and the ground up, and that means you need all the allies you can find," Shi said. 
ABIC and its network of business leaders have also been working to educate policymakers on the need for lasting reforms to bring hope and opportunity to young undocumented Dreamers who were brought to the country as children. Launched by the Texas Business Immigration Coalition (TBIC), an affiliate of ABIC, the Texas Opportunity Coalition is a growing and diverse group of Texas business and higher education leaders and associations that recognize the economic contributions Dreamers make to the state and country. Woody Hunt, senior chairman of El Paso-based Hunt Companies and ABIC cochair, explained that companies across Texas employ DACA recipients and have "seen them start their own businesses and strengthen others, and we see firsthand the way their contributions and taxes and talent help our state economy grow."

It's not just business leaders and coalitions making the economic case for pro-immigrant reforms. Carnegie Corporation and other funders also support a range of bipartisan and conservative-leaning organizations that conduct research, polling, outreach, and advocacy based on the premise that immigration is a good thing for the U.S. economy and society.

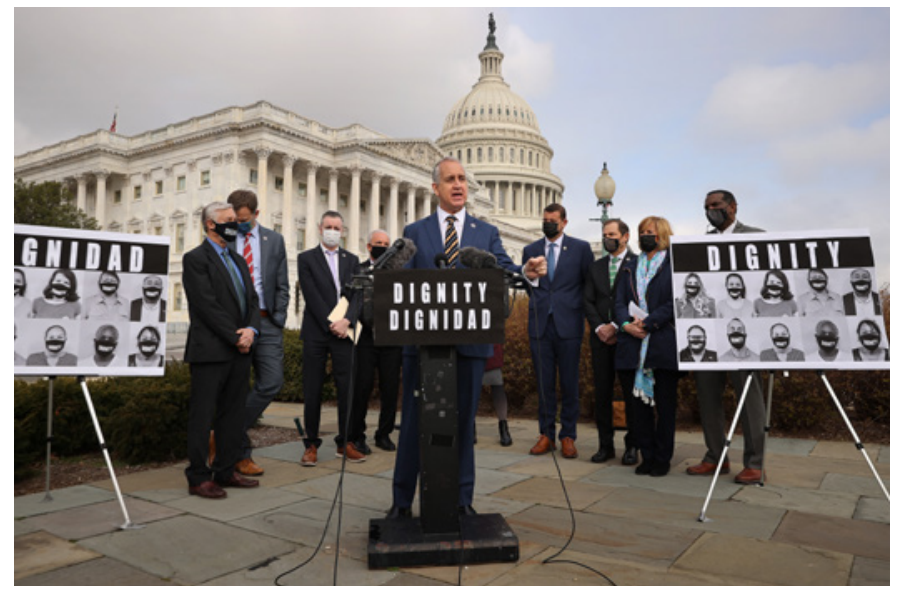

In March 2021, Rep. Mario Diaz-Balart (R-FL) speaks during a news conference about immigration outside the U.S. Capitol in Washington, D.C. Diaz-Balart joined fellow GOP members of the House to announce a plan to overhaul the immigration system, which would include giving citizenship to Dreamers, reform the asylum process, and create a 10-year path to citizenship for undocumented immigrants. CREDIT: CHIP SOMODEVILLA/GETTY IMAGES
Theresa Cardinal Brown got her start working on immigration issues as a young attorney representing businesses seeking to sponsor immigrants to come work in the United States. Today, after working on immigration issues with the federal government and advocacy groups in Washington, D.C., she leads the Bipartisan Policy Center's immigration portfolio. Brown said an important focus in the center's research, polling, and communications work is moving conservative and moderate members of Congress on the issue, primarily Republicans.

"The perception that immigrant rights and immigration reform are a project of the Democratic party has really made it hard to move people in the middle on these issues," Brown said. "So we are really trying to put a stake in the ground on issues that will bring more people to the table." One of those issues, she said, is fixing the country's legal immigration system through reforms of visa and naturalization programs.

"When I was in government, I heard time and again from Republicans and Democrats alike that if we can create a better system to manage legal flows of immigrants, then the bigger reforms will be easier to address," she said. Recently, the Bipartisan Policy Center, together with the Cato Institute and others, has conducted research on the possibility of issuing state-based visas that would give states more power to control legal immigration based on community needs. 


\section{LIBERTARIANS, CONSERVATIVES JOIN THE FIGHT}

A $\mathrm{s}$ an adjunct to the economic case for immigration, some groups take a more libertarian stance on the issue, advancing the argument that onerous restrictions on immigration limit people's basic freedoms and undermine the market economy. As director of immigration studies at the Cato Institute, Alex Nowrasteh leads a three-person team that conducts research, advocacy, and media outreach that highlights the benefits of immigration while debunking the need for stepped-up enforcement activity. In the wake of the Trump administration's COVID-related travel restrictions, it was Nowrasteh and his colleagues who issued research showing that such restrictions were ineffective in stopping the virus's spread. They have conducted similar research on the futility of immigration restrictions aimed at preventing terrorism.

"Our focus is trying to find areas where we can try to anticipate some of the big issues on the horizon and develop original research that will fill important gaps and challenge people's assumptions," said Nowrasteh. "It's all in the interest of making the case that blindly restricting immigration just doesn't make sense."

Another Carnegie Corporation grantee making a libertarian case for pro-immigrant reforms is the Niskanen Center, which combines research, commentary, and policy advocacy in Washington to advance an agenda that its website concisely describes as follows:

“The Niskanen Center's immigration agenda begins with the premise that immigration yields economic and social benefits for the United States. It is also one of the best global anti-poverty policies: Orderly migration reduces human suffering, while enhancing global stability, security, and peace."
Kristie De Peña is vice president for policy and director of immigration policy with the center. She said its work during the Trump administration focused on building alliances among Republicans and Democrats to oppose the worst anti-immigrant policies and actions adopted by the federal government. Like the Bipartisan Policy Center and others, the Niskanen Center also works on the nuts and bolts of improving the legal immigration system.

"We pay a lot of attention to nonimmigrant visas and work programs, defending the asylum program and addressing naturalization backlogs,” De Peña said.

The issue of naturalization backlogs became a key focus for the center in 2020, as it issued attention-getting research showing how Trump administration policies had created huge bottlenecks for applicants at every stage of the naturalization process. At the end of the 2019 fiscal year, its research showed the backlog of applications had reached 647,576 pending cases.

The Niskanen Center's research was picked up by media outlets across the country, and the center's staff ended up working with lawmakers to draft bipartisan legislation aimed at reducing the backlogs. "The thing we see is that many [Capitol Hill] staff and members of Congress simply do not have the capacity or the depth of experience to understand these issues in a deep and nuanced way, and so we consider ourselves a rational and reasonable voice who can work with them on commonsense solutions," said De Peña. 


\section{Pro-Immigrant Allies}

\section{in Law Enforcement}

he Police Executive Research Forum (PERF) was founded in 1976 to provide a national platform for advancing research and policies that support the law enforcement community. In the early 2000s, PERF's staff began to hear from member police departments around the country, mostly in major cities, that the lack of national action on immigration issues was causing problems in their communities. Police leaders said it was hard to build strong relationships with immigrant communities because of their fear and distrust of government.

With support from Carnegie Corporation, PERF convened police chiefs to talk about the issue and determine how law enforcement might play a role in advancing the national conversation on immigration. Since then, the Corporation has provided continuing support to PERF for a broad range of convenings and groundbreaking research on policing and immigration. An important focus of this work is sharing examples of how police departments across the country are successfully engaging with immigrant communities.
"One of the issues we are most outspoken about is why it's so important for law enforcement to be able to build trust with immigrant communities," said Chuck Wexler, executive director of PERF. "Immigrants are such an integral part of places from Houston and Chicago to New York that police can't truly do an effective job without the trust of those communities."

Wexler said the Corporation's support over many years has been critical in enabling PERF to make a powerful case that fixing the U.S. immigration system has broad support among law enforcement - and that it will lead to real improvements in public safety across the country. He said he is optimistic about the prospects for substantive changes in U.S. policy in the months and years ahead. "With police at the table alongside other interests, we can find common ground and real solutions on this issue," he said. "We have to." 


\section{FEDERAL FOCUS \\ COMPLEMENTS \\ GRASSROOTS \\ POWER BUILDING}

Yet another conservative voice deeply engaged in the debate on immigration issues is Stand Together, a foundation created by billionaire Charles Koch to work on a range of policy topics. Stand Together is the philanthropic umbrella for Americans for Prosperity, a Washington, D.C.-based policy organization committed in part to fixing immigration. Carnegie Corporation, along with other philanthropies, regularly consults with leaders from Stand Together and its funded initiatives on strategies for advancing consensus immigration reforms.

Jorge Lima, who serves as senior vice president of policy with Americans for Prosperity, said that engaging diverse interests on immigration, including conservative voices, is essential to enacting far-reaching and sustainable reforms. "We believe if you can bring people together across all these different interests and perspectives, it ensures the longevity of whatever reforms you create," he said. "Society is divided enough right now, and I think immigration is our opportunity to show people can work together to do big, important, and necessary things."

\section{We believe if you can bring people together across all these different interests and perspectives, it ensures the longevity of whatever reforms you create.}

- Jorge Lima, Senior Vice President of Policy, Americans for Prosperity
B uilding support for immigration changes among "inside the Beltway" audiences in the federal government is a key strategy the Corporation supports as part of its long-standing alliance-building strategy. From the Niskanen Center and the Cato Institute to the National Immigration Forum, many of the Corporation's immigration grantees have an active presence in Washington. For example, the Bipartisan Policy Center regularly convenes bipartisan groups of former elected officials to develop policy recommendations and hold briefings in Washington for lawmakers and their staffs.

In other examples of groups focused on encouraging progress in Washington, the National Immigration Forum regularly organizes meetings with federal lawmakers for police chiefs, faith leaders, and other constituents from their districts back home. And the George W. Bush Presidential Center is in the process of forging its own bipartisan coalition of leaders and organizations in an effort to find common ground on specific policies.

At a 2019 naturalization ceremony held at the Bush Center in Dallas, the former president laid out his hopes and dreams for the center's work on immigration reform. "Today, emotions can cloud the issue. But here at the Bush Center, we are clear-eyed about the need to enforce our borders and protect our homeland, and about the critical contributions immigrants make to our prosperity and to our way of life," he said. 
On the progressive end of the spectrum, Corporation grantee the Center for American Progress conducts Washington, D.C.-directed research and advocacy on a range of immigration issues. A recent focus for the center has been reform of the federal government's temporary protected status (TPS) system that allows nationals of designated countries to live and work in the United States instead of having to return to unsafe conditions back home. When he served as the center's vice president of immigration policy from 2015 until March 2021 (when he joined the Department of Homeland Security as deputy general counsel), Tom Jawetz said he and his colleagues regularly sought out opportunities to work with more conservative groups on TPS and other topics.

"We had open lines of communication, because I think we all recognized the power of making a broader case," Jawetz said. He cited the creation and the survival of the Obama administration's DACA program as a powerful example of progressive and more conservative voices working in coordination. "That campaign was largely led by undocumented young people fighting for protection, but it was very helpful to have large companies and conservative voices weighing in and saying this was the right thing to do," he said.

That kind of bridge building to influence Congress and the administration is critical, according to Frank Sharry, a Corporation grantee and longtime leader in the fight for federal immigration reform. Sharry currently heads America's Voice Education Fund, an organization whose mission is to "build the public support and the political will needed" to advance pro-immigrant policy reforms. Sharry said the immigrant rights movement and its funders understandably shifted their attention away from Washington after repeated failures of bipartisan comprehensive immigration reform legislation, culminating in the downfall of the "Gang of Eight" measure in 2013 .
"This was a case of funders saying you promised and you didn't deliver, and so a lot of people shifted to a focus on building power at the grass roots," said Sharry.

But Sharry argues that the power to change public policy comes from multiple sources. Using the DACA fight as a case study, he said power can be defined in four ways. There is movement power led by people and organizations at the grass roots who are closest to the problems and the pain caused by the current system. There is public opinion power that helps convince wavering lawmakers that voters will support commonsense reforms. There is electoral power that turns out immigrant and pro-immigrant voters at the polls. And, last but not least, there is alliance power that demonstrates deep and broad support from mainstream institutions from across the political spectrum.

In a briefing for funders following the Supreme Court's June 2020 decision upholding the DACA program, Sharry said his four-pronged analysis showed a path to achieving far-reaching reforms in the post-Trump era:

"For us to win big, we need a strong, vibrant, immigrant-led movement; we need deep and broad public support; we need to show that our issue works for and not against pro-immigrant candidates in contested electoral contests; and we need to cultivate meaningful support from usual and unusual allies.”

In an interview, Sharry said he understands that erecting and maintaining these four different pillars for reform is not an easy task. But it's essential. "It seems to me it's the right combination of all four that gives us the power to achieve big breakthroughs," he said. 
Sharry said he has no illusion that far-reaching legislative reforms will be an easy thing to achieve in Washington in the years to come - and that the Biden administration will be playing "a big game of catch-up" as it seeks to unravel the worst excesses of Trump's anti-immigrant agenda. But whether progress comes through baby steps or bold moves, or through legislation or administrative actions undertaken by the White House, Sharry said what happens in Washington still matters, and in a big way.

"It is a constitutional truth that Congress has authority over immigration policy, and if we want to move changes that make the U.S. immigration system more fair and more humane, then we are going to have to create the conditions that allow Congress and the White House to move forward in positive ways," Sharry said.

Toward that end, America's Voice Education Fund (with support from the Corporation and other funders) is currently focused on building the case in Washington that the American public is broadly supportive of pro-immigrant policies, especially after the COVID-19 crisis strengthened public appreciation of immigrants as essential workers (see sidebar).

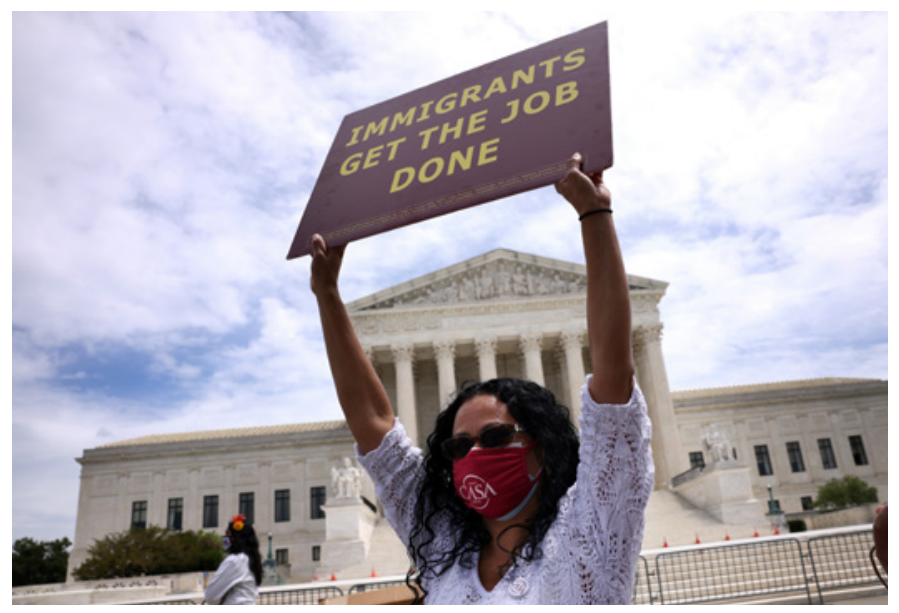

In May 2021, an immigration activist participates in a rally near the U.S. Supreme Court in Washington, D.C., in a demonstration to highlight immigrant essential worker rights. The group marched on Capitol Hill as the Senate Judiciary Committee held a subcommittee hearing on the role of essential immigrant workers in America. CREDIT: KEVIN DIETSCH/GETTY IMAGES

\section{Immigrants' Key Role} in U.S. COVID Response

$\mathrm{s}$ the coronavirus began to sweep across the United States in the spring of 2020, it quickly became clear that immigrants were playing a crucial role in the national response, even as immigrant communities were suffering some of the worst effects of the pandemic. For example:

- Immigrants are 16.5 percent of the total U.S. healthcare workforce, including 36.5 percent of home health aides and 28.7 percent of physicians.

- Immigrants are nearly a quarter of all employees in the pharmaceutical manufacturing and medical equipment and supplies manufacturing industries.

- Immigrants are critical to the U.S. food supply, representing more than 1 in 5 food sector workers. This includes 29 percent of food processing workers, 28 percent of agriculture workers, and 18 percent of food delivery workers. 


\section{COMMUNICATIONS AND MESSAGING MATTER}

T he chorus for commonsense reforms in Washington and beyond has been joined by a range of individuals and organizations engaged in research, writing, and other activities, often from a center-right perspective. New American Economy, for example, has a team of freelance journalists developing op-eds and stories about the hopes and dreams of U.S. immigrants, their contributions to their communities, the challenges they are facing, and even their favorite recipes. The National Immigration Forum conducts dedicated outreach to Christian websites on immigration issues from a faith perspective. And the Bipartisan Policy Center has a regular podcast, This Week in Immigration, that features diverse guests discussing the need and the prospects for reform across a range of immigration issues.

Linda Chavez is a former senior official in the Reagan administration who uses her podcasts, op-ed articles, and other communications to advocate for what she refers to as a "more normalized immigration system where we welcome newcomers for what they contribute to our society and the economy."

"Changing the big picture on this issue is going to require funders to support a wide-ranging communications and education effort where we create messages with broad appeal," said Chavez, whose writing and outreach on the issue at the National Immigration Forum, where she serves as a senior fellow, is partially supported by Carnegie Corporation. "Supporting immigrant communities at the grass roots is critical, but we also need to change minds and help all communities see that we are a better country when we open our doors to immigrants who want to contribute and build a better life."

\section{A TIMELY - \\ AND NECESSARY \\ - INVESTMENT}

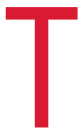
he dawn of the Biden-Harris administration marks a genuine turning point on immigration issues - not only has the new administration promised to undo the worst anti-immigrant policies of its predecessor, but it has also advanced a package of broader reforms. However, with the post-COVID recovery pushing other priorities to the sidelines for the time being, lasting fixes to the U.S. immigration system are still going to take time to achieve.

That said, advocates across the political spectrum will want to be ready to make a powerful case for action if and when the White House and Congress decide the time is right to move new pro-immigrant policies. After a decade when many funders shifted from supporting cross-sector, alliance-building approaches on immigration toward investing in the grassroots movement, many of the people and organizations focused on advancing common-ground federal reforms say they are in urgent need of additional support. Interviews for this report affirmed that groups have been laying off organizers, downscaling programs, and otherwise reining in the scope of their alliance-building work.

Felicia Escobar Carillo serves as chief of staff to Ur Jaddou, director of U.S. Citizenship and Immigration Services, and previously served as special assistant to the president for immigration policy during the Obama administration. Escobar Carrillo, who has also worked in philanthropy, said she has watched foundations waver between supporting bottom-up and D.C.-focused solutions on immigration issues when they should really be embracing both. "We need the progressive side to be pushing for a more equitable and humane system at the same time that we need to have strong alliances making the case that immigration benefits all of us," she said.

Another longtime leader on immigration issues in Washington is Patty First, who worked on Capitol Hill before helping to start the National Immigration Forum's Bibles, Badges, and Business initiative in 2012. First said that in the wake of the 2020 election, alliance-building 
groups need more staffing and infrastructure so they can step up their critical work now. "There is always a lag time between making those investments and the time when you need to mount a campaign, and foundations can be notoriously slow in deciding to move resources out the door," First said.

The Corporation's Geri Mannion agreed that the time is now to invest in what she called "both-and" approaches to addressing immigration issues. "People think everything happens in an instant, but it takes years," she said. "You need to build relationships, build a research base, and build the messaging and the case for the changes you want."

In the wake of the COVID-19 crisis, the nation has a fresh understanding of how immigrants play a vital role in our economy and our communities. The public also has a new and more nuanced awareness of the systemic barriers that endanger the health, lives, and livelihoods of immigrants and communities of color. Turning that awareness into broad-based action in support of immigrants is going to require new investments to activate and align diverse partners in the decades-long fight for change.

This is an all-hands-on-deck moment - and it's a moment ripe with possibility for immigrants and the nation.

\section{People think everything happens in an instant, but it takes years. You need to build relationships, build a research base, and build the messaging and the case for the changes you want.}

- Geri Mannion, Director, Strengthening U.S. Democracy, Carnegie Corporation of New York

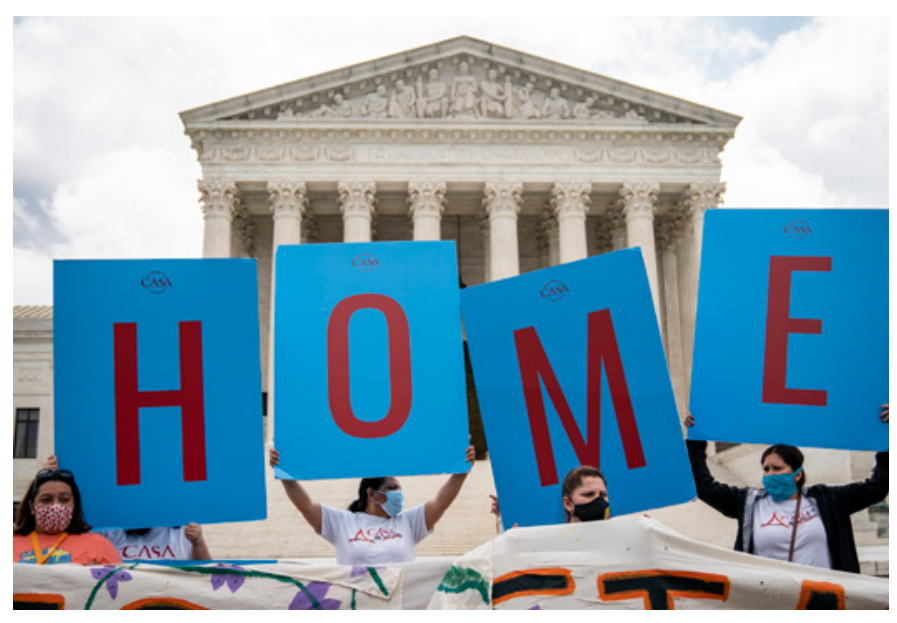

On June 18,2020, DACA recipients and their supporters rally outside the U.S. Supreme Court in Washington, D.C. The Supreme Court, in a 5-4 decision, denied the Trump administration's attempt to end DACA, the Deferred Action for Childhood Arrivals program. CREDIT: DREW ANGERER/GETTY IMAGES 


\section{A History of Supporting Bipartisan Solutions}

Carnegie Corporation of New York's investments in alliance building on immigration issues reflect its long-standing commitment to creating broad-based support for solutions to urgent issues confronting the United States and the world. The following timeline highlights how the

Corporation has led and supported important bipartisan initiatives over the last several decades.

\section{4 | White House Fellows Program}

President Lyndon B. Johnson created the White House Fellows program after it was proposed by Carnegie Corporation President John W. Gardner. The program, developed with Corporation grants, provides young people with an opportunity to work at the highest levels of government. It has continued across Democratic and Republican administrations for more than a half century and has enrolled many current leaders across both parties.

\section{5 | Head Start Program}

A mainstay of U.S. efforts to promote school readiness, the Head Start program has received strong bipartisan support since it was created as an essential component of the War on Poverty. Throughout the 1960s, the Corporation supported research that proved crucial in securing and safeguarding funds for the groundbreaking program, which enrolls more than one million preschool children and their families each year.

\section{Pell Grants Program}

Between 1967 and 1973, the Carnegie Commission on Higher Education, financed by the Corporation and sponsored by its sister institution, the Carnegie Foundation for the Advancement of Teaching, conducted a study outlining a massive program of higher education federal assistance. As a result of this work, Congress created the federal Pell Grants program, which supported 6.7 million students in the 2019-20 school year. The program has attracted broad support across both political parties as a critical tool for helping young people from low-income families attain a higher education.

\section{Aspen Institute Congressional Program} The Aspen Institute Congressional Program is a nongovernmental, nonpartisan educational program for members of Congress. Carnegie Corporation of New York provided the initial grants for the program and continues to fund Aspen Institute's influential congressional retreat program on international security.

\section{8 | Carnegie Commission on Science, Technology, and Government}

From 1988 to 1993, the Corporation-funded Carnegie Commission on Science, Technology, and Government set out to assess and improve how the federal government and the states incorporate scientific and technical knowledge into policy and administrative decision-making. The commission's ongoing impact, as well as its recommendation that the role of the president's science advisor be upgraded and enhanced, can be seen in the ongoing work of the White House Office of Science and Technology Policy.

\section{0 | Committee on Reducing the Nuclear Danger}

The Corporation initiated a series of grants to bring together experts concerned about post-Soviet nuclear nonproliferation. The Committee on Reducing the Nuclear Danger was formed first, followed by the Prevention of Proliferation Task Force, which was funded through grants to the Brookings Institution. The task force's report subsequently influenced development of the bipartisan 1991 Nunn-Lugar Cooperative Threat Reduction Program, which has brought about the deactivation of thousands of nuclear warheads, missiles, bombers, and other deadly weapons and delivery systems. 


\section{Help America Vote Act}

In 2001, the Corporation funded a joint research project of the Massachusetts Institute of Technology and the California Institute of Technology aimed at developing new voting technologies that would lead to a secure and affordable uniform voting system that could be employed throughout the 50 states. The resulting report called for investment by the federal government in research and development of voting equipment technologies as well as an independent agency to oversee performance and testing. The Help America Vote Act, signed into law by President George W. Bush, was largely an outgrowth of this work.

\section{2 | Bipartisan Campaign Reform Act}

This hallmark campaign finance legislation, the first passed since 1974, was cosponsored by Senator John McCain (Republican of Arizona) and Senator Russ Feingold (Democrat of Wisconsin) and put strict limits on campaign contributions. The Bipartisan Campaign Reform Act (also known as the McCain-Feingold Act) followed years of work by Corporation grantees working to reform how campaigns are funded.

\section{3 | The Civic Mission of Schools}

In partnership with the Center for Information and Research on Civic Learning and Engagement, now at Tufts University, Carnegie Corporation published the seminal report, The Civic Mission of Schools, as part of an effort to restore civics to the K- 12 curriculum. This was developed by a broad right-to-left coalition. The Corporation has also funded advocacy efforts toward this goal on the local and national levels.

\section{Track II Diplomacy}

Building upon its Cold War-era achievement of an informal communications network among Soviet and American leaders, the Corporation played a major role in supporting a series of unofficial diplomatic dialogues with representatives of the United States, the Democratic People's Republic of Korea, and other regional powers. These talks ultimately led to improved bilateral relations and a decisive breakthrough for the resumption of the nuclear six-party talks, according to North Korea's ambassador to the United Nations. Earlier Track II talks with Pakistan and India aimed to persuade the two nuclear powers to work together to establish security.

\section{3 | Border Security, Economic Opportunity,} and Immigration Modernization Act Following years of advocacy by Corporation grantees, the Senate passed this comprehensive immigration reform bill with strong bipartisan support. Although the Border Security, Economic Opportunity, and Immigration Modernization Act was never taken up for a vote in the House of Representatives, the support of 68 Senators demonstrated how much agreement there is on this issue across party lines.

\section{6 | Election Administration}

The Corporation supported the National Academy of Sciences in advance of the 2016 elections toward a research project on the future of voting technology. The research resulted in a report, Securing the Vote: Protecting American Democracy, released in September 2018.

\section{Preparing for an Accurate Count in the 2020 Census}

The Corporation joined other partners from philanthropy, the nonprofit sector, business, government, and academia in support of ensuring an accurate, nonpartisan 2020 Census. It also joined in establishing a funder collaborative at the New Venture Fund, to educate decision makers on census design and implementation and respond to arising challenges that would impede an exact count. 


\section{ABOUT THE AUTHOR}

William H. Woodwell, Jr., is a writer, editor, and communications consultant who works with leading foundations and nonprofits to tell powerful stories about their work.

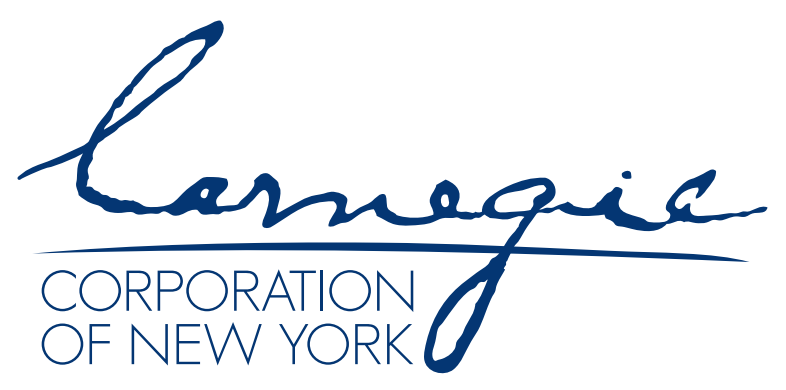

(C) 2021, Carnegie Corporation of New York 


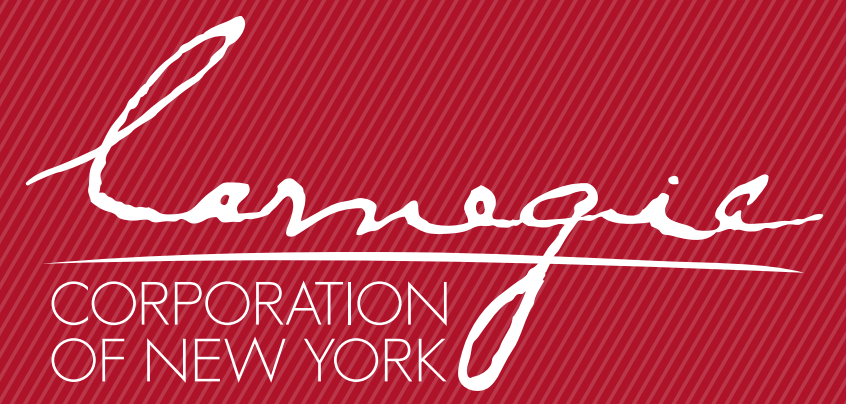

Carnegie Corporation of New York was established by Andrew Carnegie in 1911 to promote the advancement and diffusion of knowledge and understanding. In keeping with this mandate, the Corporation's agenda focuses on the issues that he considered of paramount importance: international peace, the advancement of education and knowledge, and the strength of our democracy. 